\title{
Indigenous Ways of Living vs. the Human Commodity or Perhaps you should burn your PhD?
}

\author{
Willie Brim ${ }^{1}$ and Pete Harrison ${ }^{2}$
}

This paper intends to show how what is essential to Indigenous perspectives represents an absolute and irreconcilable opposition to the imperatives of capitalist civilization. This is explored through an analysis of the commoditization of human beings in the global economic system and an enquiry into the meaning of 'knowledge' as defined by Westernized thought - a conceptualization essentially shared by theorists of Decolonization. The role of the University, as a function of capitalist civilization and, crucially for this essay, in the continuing elimination of Indigenous culture, is also brought into focus. [Article copies available for a fee from The Transformative Studies Institute. E-mail address: journal@transformativestudies.org Website: http://www.transformativestudies.org (C2015 by The Transformative Studies Institute. All rights reserved.]

KEYWORDS: Indigenous, Decolonization, Knowledge, Capitalism, Civilization.

\footnotetext{
${ }^{1}$ Willie Brim was born on a Mission and, as a young man in the late 1970's, spent many weekends in the local lock-up for fighting the police. He is renowned in Far North Queensland for his perseverance and engaging personality and the music he has made through the bands Mantaka and Zennith. Willie is Buluwanydji and still lives on his ancestral lands with his family where he fights to keep the old ways alive.

${ }^{2}$ Pete Harrison was born in Brisbane but grew up in the UK, where he was involved in workplace, anarchist and ultra-left activism through the 1980's and '90's. He is half of the duo who wrote Nihilist Communism ('still one of the most hard-nosed books to call the left to account'). Since becoming a teacher he has also written for Mathematics Teaching.

Willie and Pete have had work published in the National Indigenous Times and elsewhere, and are presenters on an Indigenous literacy project called Yarning Strong, produced by Oxford University Press. They operate an embryonic website: www.bulwaicollective.org. Acknowledgments: Thanks to Greg Smith, Lewis and Clark College, Portland, Oregon, for pointing us to North American perspectives.
} 